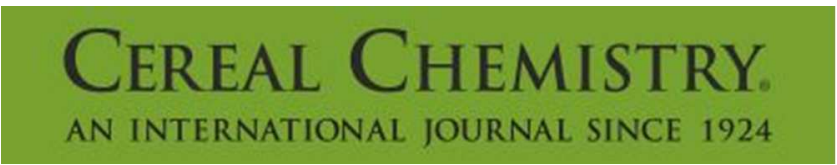

\title{
Characterization of durum wheat semolina by means of a rapid shear-based method
}

\begin{tabular}{|c|c|}
\hline Journal: & Cereal Chemistry \\
\hline Manuscript ID: & CCHEM-10-13-0224-R.R2 \\
\hline Manuscript Type: & Research \\
\hline Date Submitted by the Author: & $\mathrm{n} / \mathrm{a}$ \\
\hline Complete List of Authors: & $\begin{array}{l}\text { Marti, Alessandra; Università degli Studi di Milano, DeFENS, Department of } \\
\text { Food, Nutritional and Environmental Sciences } \\
\text { Cecchini, Cristina; Consiglio per la Ricerca e la Sperimentazione in } \\
\text { Agricoltura (CRA-QCE), } \\
\text { D'Egidio, Maria Grazia; Consiglio per la Ricerca e la Sperimentazione in } \\
\text { Agricoltura (CRA-QCE), } \\
\text { Dreisoerner, Jens; Food Division, Brabender GmbH \& Co. KG, } \\
\text { Pagani, M. Ambrogina; Università degli Studi di Milano, DeFENS, } \\
\text { Department of Food, Nutritional and Environmental Sciences }\end{array}$ \\
\hline Area of Expertise: & Gluten, Pasta, Rheology \\
\hline
\end{tabular}


$3 \quad$ Alessandra Marti ${ }^{1, *}$, Cristina Cecchini ${ }^{2}$, Maria Grazia D’Egidio ${ }^{2}$, Jens Dreisoerner ${ }^{3}$, $4 \quad$ Maria Ambrogina Pagani ${ }^{1}$

5

$6{ }^{1}$ Department of Food, Environmental and Nutritional Sciences - Università degli Studi di Milano, 7 via Giovanni Celoria 2, 20133 Milan, Italy

$8{ }^{2}$ Consiglio per la Ricerca e la Sperimentazione in Agricoltura (CRA-QCE), via Cassia 176, 00191

9 Rome, Italy

$10{ }^{3}$ Food Division, Brabender GmbH \& Co. KG, 51-55 Kulturstrasse 47055, Duisburg, Germany 11

12 *Corresponding author:

13 Dr. Alessandra Marti

14 2, Via G. Celoria

1520133 Milan, Italy

16 E-mail address: alessandra.marti@unimi.it

17 Phone: +390250316640 
18 Keywords: durum wheat semolina; gluten aggregation; semolina quality; pasta cooking behaviour 19

20 Abbreviations: AU, Arbitrary Units; BE, Brabender Equivalent; PMT, peak maximum time 21 
22 Abstract

23 A rapid shear-based test - the GlutoPeak, recently proposed by Brabender GmbH \& Co. (Duisburg, 24 Germany) - was used to investigate gluten aggregation properties of durum wheat semolina and to 25 relate them to pasta cooking behavior. Thirty semolina samples were characterized by means of the 26 conventional approaches used for pasta-quality prediction (protein content, Gluten Index, 27 alveographic indices). All samples were also analyzed by the GlutoPeak test obtaining three 28 parameters: maximum peak torque, maximum peak time, area under the peak. The GlutoPeak 29 indices were significantly correlated with protein content, Gluten Index, and W alveographic 30 parameter. The cooking quality of pasta obtained from the 30 semolina samples was evaluated by 31 sensory analysis in terms of stickiness, bulkiness, firmness, and overall quality. The GlutoPeak 32 indices were significantly correlated with the sensorial parameters. In comparison with the 33 alveographic test - presently the most used rheological approach for semolina characterization 34 GlutoPeak analysis presents some advantages represented by a smaller amount of sample $(9 \mathrm{~g})$, a 35 shorter time (less than 5 minutes) and the possibility to be carried out by untrained analysts In 36 addition, following testing with larger sample numbers, the GlutoPeak has the potential to be used 37 instead of the Gluten Index as a rapid and reliable approach for medium quality semolina 38 characterisation. 
Semolina from durum wheat is recognized as the most suitable raw material for dried pasta production due to the technological functionality of proteins which are unique in assuring low stickiness and good firmness to cooked pasta (D'Egidio et al 1990; Feillet and Dexter 1996). In spite of the extensive research on this topic, we are still far from the ideal test for semolina characterization. Up to now, the prediction of semolina aptitude to guarantee pasta products with optimal cooking behavior is mainly based on protein content (Feillet and Dexter 1996) and rheological approaches providing useful information for elasticity, extensibility, and resistance to overcooking (Dexter and Matsuo 1980; D’Egidio et al. 1990; Weegels et al. 1996). The rheological tests currently used for semolina characterization, together with their points of strength and weaknesses, are highlighted in Table I. Some of them are time consuming and require a large amount of sample; others are highly influenced by the analyst. Thus the development of a rapid and reliable test is still challenging.

The GlutoPeak has been recently proposed for the evaluation of flour quality from common wheat. In particular, it provides a measurement of the aggregation behaviour of gluten, as it is present in wheat flour, coarse grain or vital gluten. The test is carried out using small sample sizes (8-10 g), high flour : water ratio (about 9:10), high speed (1900-3000 rpm), and short time $(<10$ minutes). Moreover, the Glutopeak does not require gluten isolation or any kind of samples handling. Up to now, the GlutoPeak supplied good indications to characterize common wheat flours (Melnyk et al. 2011; Kaur Chandi and Seetharaman 2012), while very few information is available for durum wheat products (Marti et al. 2013).

The aim of the work was to investigate the gluten aggregation properties of semolina samples different in their technological performances by this new rheological approach and the results were compared with those of the conventional approaches widely used for semolina classification. Finally, to better understand the aggregation phenomena at a molecular scale in semolina samples of different performances, we investigated the network formation at different mixing time by using an ultrastructural approach. 
66

67

68

69

70

71

72

73

74

75

76

77

78

79

80

81

82

83

84

85

86

87

88

89

90

\section{Materials and Methods}

\section{Samples}

Thirty durum wheat semolina samples, different in protein quantity and quality, were considered in this study. Durum wheat kernels were obtained from the experimental trials of the durum wheat national network (D'Egidio et al 2013). All the durum wheat grains were milled using the same pilot milling plant (Buhuler MLU 202, Switzerland; semolina yield: 60-65\%), so minimizing the differences in particle sizes related to milling conditions.

\section{Conventional Methods}

Semolina samples were characterized by means of standard methods in terms of protein content (AOAC 920.87), gluten index (ICC 158), and alveographic indices (UNI 10453).

Presently, semolina classification is based on alveographic parameters, that show a strong relationship with pasta cooking quality (D’Egidio et al 1990). On the basis of the conventional alveographic test, semolina samples were divided into three classes of quality: poor $\left(\mathrm{W}<180 * 10^{-4}\right.$ J), medium $\left(180<\mathrm{W}<250 * 10^{-4} \mathrm{~J}\right)$, and good $\left(\mathrm{W}>250 * 10^{-4} \mathrm{~J}\right)$ according to the UNI 10453 standard (1995).

\section{GlutoPeak Test}

Gluten aggregation properties were measured using the GlutoPeak (Brabender GmbH and Co KG, Duisburg, Germany). An aliquot of $9 \mathrm{~g}$ of sample was dispersed in $10 \mathrm{ml}$ of distilled water. Sample temperature was maintained at $35^{\circ} \mathrm{C}$ by circulating water through the jacketed sample cup. The paddle was set to rotate at $2750 \mathrm{rpm}$ and each test ran for $5 \mathrm{~min}$. During the test, the sample slurry was subjected to intense mechanical action, promoted by the speed of the rotating element. 
91 This condition allows the formation of gluten; at the same time a strong increase of the torque curve 92 is registered. Further mixing destroys the network and the torque curve would decline.

93 The resulting torque curve has the typical shape shown in Fig. 1. The main indices 94 automatically evaluated by the software are: 1) the maximum torque (expressed in Brabender 95 Equivalents - BE), corresponding to the peak occurring as gluten aggregates; 2) the peak maximum 96 time (PMT), corresponding to the time before torque falling off when gluten breaks down. In 97 addition, the area under the peak - equivalent to energy - was calculated by integrating the curve 98 and expressed in arbitrary unit (AU). Measurements were performed in triplicate.

99

100

101

102

103

104

105

106

107

108

109

110

111

112

113

114

115

116

\section{Microstructural features}

One poor semolina (sample 5) and one good semolina (sample 26) were chosen for a qualitative analysis of the changes in microstructural features during the test. Samples were taken at different moments, as indicated in Fig. 1: first stage of mixing (t1), after gluten formation (t2), and after its breakdown (t3) and observed by means of an Olympus BX50 microscope (Olympus, Tokyo, Japan). $0.1 \%$ toluidine blue was used for staining protein (Kirana et al. 2009).

\section{Pasta making}

Dried spaghetti were produced according to D'Egidio et al (1990). In short, semolina and water (35\% dough moisture) were mixed and extruded into a spaghetti shape (1.65 $\mathrm{mm}$ diameter) in an experimental press $(30 \mathrm{~kg} / \mathrm{h}$; Namad Press, Namad, Italy). All samples were dried in an experimental drying cell (Afrem dryer, Afrem, France) using a low temperature drying cycle $\left(50{ }^{\circ} \mathrm{C}\right.$ max for $14 \mathrm{~h}$ ) and stored at room temperature until analyzed.

\section{Sensory analysis}

Sensory evaluation was carried out according to D'Egidio et al (1993). The sensory analysis was performed by a highly trained panel of 8 experts. Stickiness, the material adhering to the 
117 surface of cooked pasta, was evaluated by visual inspection with the aid of standard reference 118 samples and by handling. Bulkiness, which is related to stickiness, measures the adhesion degree of 119 pasta strands to each other and was evaluated both visually and manually. Firmness relates to the 120 resistance of cooked pasta to chewing. Each parameter was scored on a 10-100 scale: $100=$ absent 121 for stickiness and bulkiness; 100 = very good for firmness. The score of each sensory judgment 122 component was the mean of the values given by the panelists. The overall score was the average of 123 the means for stickiness, bulkiness, and firmness.

124

125

\section{Statistical analysis}

Data were processed by Statgraphic Plus for Windows v. 5.1. (StatPoint Inc., Warrenton, VA, USA) and significant correlations were performed adopting the Pearson correlation analysis procedure.

\section{Results and Discussion}

\section{GlutoPeak and conventional tests}

Results for the conventional parameters (protein content, Gluten Index, W alveographic) and the new ones (maximum torque, peak maximum time, and energy, calculated from the GlutoPeak curve) for semolina characterisation are shown in Table II, in which mean, standard deviation, and coefficient of variation for each sample were reported. The Alveographic test exhibited the highest variability among the rheological approaches. The coefficient of variation for the $\mathrm{W}$ alveographic ranged from 16.7 to 2.5 , with a median value of 5.4. As regard the coefficients of variation of Gluten Index, they were in the $0.7-9 \%$ range, with a median of $1.99 \%$. The indices obtained from the Glutopeak test exhibited the lowest variability: the maximum coefficient of variation for the maximum torque, the peak maximum time, and the energy were $2.6,5.6$, and $4.2 \%$, respectively; median values for these indices were $0.7,0$, and 1.1 , respectively. These results suggested that the new approach exhibited higher repeatability than the conventional tests. 
All the samples showed a peak between 90 and 158 seconds, except sample 9 and 10 which

144

145

146

147

148

149

150

151

152

153

154

155

156

157

158

159

160

161

162

163

164

165

166

167

did not exhibit a peak until 10 minutes of analysis, suggesting poor gluten aggregation properties in the hydration conditions used in this study. Based on the alveographic index, sample 9 and sample 10 are classified in poor quality category. Pasta samples prepared from these two samples exhibited high stickiness and high bulkiness after cooking (Table III). The cooking behavior was in accordance with the GlutoPeak results and their interpretation: the poor gluten aggregation capacity of semolina samples resulted in a scarce capacity to keep starch granules inside the protein matrix. On the contrary, the Gluten Index test was not able to highlight the low quality of samples 9 and 10. However, both samples exhibited an aggregation peak when a less diluted slurry $(9 \mathrm{~g}$ sample in $9 \mathrm{~g}$ water) was used (data not shown), highlighting the capability to form a network, as indicated by the conventional methods.

Considering the whole sample set $(\mathrm{n}=30)$, a significant positive correlation between protein content, maximum torque $(r=0.54, p<0.01)$ and the area under the curve (energy) was observed $(r=0.47, p$ $<0.01$; Table IV). As for the quality of gluten, the statistical analysis showed significant positive correlations between $\mathrm{W}$ alveographic and peak maximum time $(\mathrm{r}=0.35 ; \mathrm{p}<0.05)$ and maximum torque $(\mathrm{r}=0.56, \mathrm{p}<0.01)$. The energy was significantly correlated both to the Gluten Index $(\mathrm{r}=$ $0.47, \mathrm{p}<0.01)$ and $\mathrm{W}$ alveographic $(\mathrm{r}=0.65, \mathrm{p}<0.01)$. suggesting that samples characterized by strong gluten required high energy to aggregate into a cohesive matrix.

According to the Gluten Index test, all the samples with a value higher than 80 fall within the good quality category, based on W alveographic index (UNI 10453, 1995) (Fig 2a). Sample 14 with a low $\mathrm{W}$ value $(\mathrm{W}=182)$ exhibited a very high $\mathrm{GI}$ value $(\mathrm{GI}=87)$. Semolina $1,2,3$, 6, and 7 with a GI $<50$ correctly fall in the poor quality class. Whereas, samples $4,5,9$, and 10 showed medium GI values $(67<\mathrm{GI}<70)$ even if , according to the present Italian classification method, they belong to the poor quality class $(\mathrm{W}<180)$. Moreover, noteworthy samples 2 and 9 had similar protein content and W index but a very different Gluten Index (42 and 67, respectively). 
168 The GlutoPeak was able to distinguish the samples of high quality (area>2400 AU) from those of 169 low quality (area $<2400$ AU) (Fig 2b). As expected, medium quality semolina exhibited an 170 intermediate behaviour. In particular, these latter can be divided in two groups: the first one with 171 area $<2400 \mathrm{AU}$ (samples 11, 16, 18, and 19), and a second one with area $>2400$ AU (samples 12, $17213,14,15,17$, and 20). Most of the samples belonging to the latter group exhibited good pasta 173 quality attributes (Table III). Summarizing, both the approaches (GlutoPeak and Gluten Index) 174 correctly discriminate samples of high quality from those of very poor quality. Whereas, the output 175 is not univocal in the case of medium quality samples (Gluten Index in the 30-65 range).

176

177

178

179

180

181

182

183

184

185

186

187

188

189

190

191

192

193

\section{Microstructural features of semolina during GlutoPeak test}

Microscopic images of poor (sample 5) and good quality (sample 26) semolina sample taken in three subsequent moments during the test are shown in Fig. 3. The gluten aggregation properties showed strong differences since from the first stages of mixing. The higher protein content of semolina of good quality $(13.1 \%)$ compared with that of poor quality $(12.2 \%)$, together with the different protein quality shown by conventional tests (sample 5 exhibited lower Gluten Index and W alveographic index compared with sample 26), explains the ability to quickly create protein agglomerates in good quality semolina (Fig. 3 a,c), compared to sample 5 (Fig. 3 b,d). When gluten aggregation was completed, the maximum torque was recorded by the instrument, and the formation of a well-structured network characterized by long protein fibrils surrounding starch granules was recognizable. The higher the semolina quality, the more thick and continuous is the protein network (Fig. 3 c). The prolonged mixing at high speed causes an inevitable rupture of the protein network (Fig. 3e, f). This phenomenon is particularly evident when the protein quality of semolina is poor (Fig. 3 f). For the good quality semolina sample, in fact, the protein network continues to show a continuous structure even after more than two minutes of mixing (Fig. 3 e).

\section{GlutoPeak and pasta quality}


194 The results of sensory evaluation of cooked pasta prepared from semolina samples are 195 reported in Table III. The energy required for gluten aggregation, as reported above (Table II), was 196 calculated as the area under the curve; for this reason the energy values consider both the peak 197 maximum time and the maximum peak torque, and it seems to be an important complimentary 198 index that provides additional information. The correlation coefficients for the semolina samples are 199 shown in Table V. When all the thirty samples were considered, the maximum torque was 200 significantly $(\mathrm{p}<0.01)$ correlated with stickiness $(\mathrm{r}=0.55)$, bulkiness $(\mathrm{r}=0.42)$, and the overall quality $201(\mathrm{r}=0.38)$ of cooked pasta. As regard the energy, it was significantly $(\mathrm{p}<0.01)$ correlated with 202 stickiness $(r=0.56)$, bulkiness $(r=0.50)$, and the overall quality $(r=0.49)$ of cooked pasta. 203 Semolina presenting high GlutoPeak energy values gave a product characterized by low stickiness 204 and bulkiness. These results confirmed that raw materials with good aggregation properties (high 205 torque during the test) resulted in a product with high overall quality. In the conditions used in this 206 study, none of the GlutoPeak indices was significantly correlated to the firmness of the cooked 207 pasta (Table V).

208 Since it was noticed (Fig 2) that one of the weakness of the Gluten Index tests was the low capacity 209 of discriminating semolina of medium quality, correlation was carried out also taking into 210 consideration only the samples with a Gluten Index in the 30-65 range (Table V). For this set, the 211 Gluten Index did not show any significant correlation with any of the pasta quality attributes.

212 Moreover, the correlation between W alveographic and pasta sensory quality was less strong 213 (firmness) or even not significant (stickiness, bulkiness, and overall score). Whereas, the significant 214 correlation between the GlutoPeak parameters and stickiness and bulkiness is of significant 215 importance, since these two attributes are often difficult to be predicted.

\section{Conclusions}

218 Overall, the results obtained from the screening of 30 durum wheat semolina samples are 219 encouraging in showing GlutoPeak as a fast and reliable approach for semolina characterization. 
220 GlutoPeak indices were significantly correlated with the conventional parameters used for semolina

221 characterization and pasta-quality prediction, with the advantages of requiring few minutes of 222 analysis (less than 5 minutes) and small amount of sample $(9 \mathrm{~g})$, properties of great interest in all 223 sectors of durum wheat transformation chain. Moreover, the results obtained using the GlutoPeak 224 are encouraging to propose this new approach as a valid screening tool for durum wheat quality.

225

226

227

228

229

230

231

232

233

234

235

236

237

238

239

240

241

242

243

244

\section{Acknowledgements}

A.M. is the grateful recipient of a postdoctoral fellowship from the European Social Fund

\section{References}

Alamri, M. S., Manthey, F., Mergoum, M., Elias, E., and Khan, K. 2009. Use of glutograph instrument in durum wheat quality evaluation. Plant Sci. Res. 2: 23-32.

AOAC 1999. Official Methods of Analysis, Association of Official Analytical Chemists, Gaithersburg, MD.

D’Egidio, M. G., Mariani, B. M., Nardi, S, Novaro, P., and Cubadda, R. 1990. Chemical and technological variables and their relationships: A predictive equation for pasta cooking quality. Cereal Chem. 67: 275-281.

D’Egidio, M. G., Mariani, B. M., Nardi, S., and Novaro, P. 1993. Viscoelastograph measures and total organic matter test: suitability in evaluating texture characteristics of cooked pasta. Cereal Chem. 70: 67-72.

D’Egidio, M. G., Moscaritolo, S., Marti, A., and Pagani M. A. 2013. Adaptation of the Mixolab for durum wheat testing. Pages 89-98 in: Mixolab. A new approach to rheology. A. Dubat, C. M. Rossel and E. Gallagher, eds. AACC International press: St Paul, MN.

D’Egidio, M. G., Cecchini, C., Gosparini, E., Arcangeli, A., Mortaro, R., and Moscaritolo, S. 2013. Caratteristiche qualitative delle varietà in prova nel 2011-2012. Molini d'Italia, 1, 28-45. 
245 Dexter, J .E., and Matsu, R. R. 1980. Relationship between durum wheat protein properties and 246 pasta dough rheology and spaghetti cooking quality. J. Agr. Food Chem. 28: 899-902.

247 Dubat, A. 2013. The Mixolab. Pages 3-13 in: Mixolab. A new approach to rheology. A. Dubat, C. 248 M. Rossel and E. Gallagher, eds. AACC International press: St Paul, MN.

249 Faridi, H. A., and Rasper, V.F. 1987. The Alveograph Handbook. AACC International press: St 250 Paul, MN.

251 Feillet, P., and Dexter, J. E. 1996. Quality requirements of durum wheat for semolina milling and 252 pasta production. Pages 95-131 in: Pasta and noodle technology. J.E: Kruger, R. R. Matsuo 253 and J. W. Dick, eds. Pp. 95-131. AACC International press: St Paul, MN.

254 ICC 1995. Official Methods of International Association for Cereal Science and Technology 255 Method, Wien, Austria.

256 Kaur Chandi, G., and Seetharaman, K. 2012. Optimization of gluten peak tester: a statistical 257 approach. J. Food Quality 35: 69-75.

258 Marti, A., Seetharaman, K., and Pagani, M. A. 2013. Rheological approaches suitable for 259 investigating starch and protein properties related to cooking quality of durum wheat pasta. J. $260 \quad$ Food Quality 36: 133-138.

261 Kirana, C., Ward, T., Jordan, T.W., Rawson, P., Royds, J., Shi, H.J., Stubbs, R., and Hood, K. 2009. 262 Compatibility of toluidine blue with laser microdissection and saturation labeling DIGE. 263 Proteomics 9: 485-490.

264 Melnyk, J. P., Dreisoerner, J., Bonomi, F., Marcone, M. F., and Seetharaman, K. 2011. Effect of the 265 Hofmeister series on gluten aggregation measured using a high shear-based technique. Food $266 \quad$ Res. Int. 44: 893-896.

267 Sietz, W. 1987. A new method to test gluten quality. Pages 305-326 in: Cereal science and 268 Technology. Proceeding of the 23rd Nordic cereal congress L. Munk., eds. Danish cereal 269 society: Copenhagen. 
270 UNI 10453 1995. Grano duro e semole. Determinazione delle caratteristiche reologiche mediante 271 alveografica. UNI, Ente Nazionale Italiano di Unificazione, Milano, Italy.

272 Weegels, P. L., Pijpekamp, A. M. van de, Graveland, A., Hamer, R. J., and Schoreld, J. D. 1996. 273 Depolymerization and repolymerisation of wheat glutenin during dough processing. I. 274 Relationship between glutenin macropolymer content and quality parameters. J. Cereal Sci. 275 23: 103-111.

276 
Table I

$278 \quad$ Rheological approaches currently used for semolina characterization

$279 *$ including sample preparation and cleaning

Test

Principle

Time required*

Gluten Index Method

It measures the amount of

$\sim 15 \mathrm{~min}$ wet gluten remaining on a specially constructed sieve after centrifugation under standardized conditions (ICC 158, AACC 38-12)

\author{
Glutograph Test
}

It measures the extensibility and elasticity of washed wet gluten, isolated from flour (Sietz 1987; Alamri et al.,2009)

Alveographic Test

It measures resistance to $\sim 50-60 \mathrm{~min}$

Sample amount required $\sim 15 \min$ 3-D extension of a thin sheet of dough, prepared at a constant hydration level (43.3\%) (Faridi \& Rasper 1987; D'Egidio et al., 1990)

Mixolab Test

It measures changes in consistency of dough subjected to the simultaneous action of mixing and temperature (Dubat 2013; D'Egidio et al., 2013)

$10 \mathrm{~g}$

$10 \mathrm{~g}$

Influence of the analyst

high

$250 \mathrm{~g} \quad$ very high

$50 \mathrm{~g} \quad$ low 
Table II

282

Semolina characteristics

\begin{tabular}{|c|c|c|c|c|c|c|c|}
\hline 283 & Semolina & \multicolumn{3}{|c|}{ Conventional quality indices } & \multicolumn{3}{|c|}{ GlutoPeak indices } \\
\hline 284 & samples & $\begin{array}{c}\text { Protein } \\
(\mathrm{g} / 100 \mathrm{~g} \mathrm{db})\end{array}$ & Gluten Index & $\begin{array}{l}\text { W alveographic } \\
\left(* 10^{-4} \mathrm{~J}\right)\end{array}$ & $\begin{array}{l}\text { Maximum torque } \\
\text { (BE) }\end{array}$ & $\begin{array}{c}\text { Peak } \\
\text { maximum time } \\
(\mathrm{s})\end{array}$ & $\begin{array}{l}\text { Energy } \\
(\mathrm{AU})\end{array}$ \\
\hline \multirow{4}{*}{285} & 1 & $10.9 \pm 0.04$ & $31 \pm 2.8$ & $135 \pm 19.7$ & $26.5 \pm 0.7$ & $85.0 \pm 1.4$ & $1899 \pm 40.2$ \\
\hline & 1 & $(\mathrm{CV}=0.3 \%)$ & $(\mathrm{CV}=9.1 \%)$ & $(\mathrm{CV}=14.7 \%)$ & $(\mathrm{CV}=2.7 \%)$ & $(\mathrm{CV}=1.7 \%)$ & $(\mathrm{CV}=2.1 \%)$ \\
\hline & & $12.2 \pm 0.04$ & $42 \pm 2.8$ & $92 \pm 5.3$ & $27.0 \pm 0$ & $107.5 \pm 0.70$ & $1749 \pm 26.1$ \\
\hline & 2 & $(\mathrm{CV}=0.3 \%)$ & $(\mathrm{CV}=6.7 \%)$ & $(\mathrm{CV}=5.8 \%)$ & $(\mathrm{CV}=0 \%)$ & $(\mathrm{CV}=0.7 \%)$ & $(\mathrm{CV}=1.5 \%)$ \\
\hline \multirow[t]{3}{*}{286} & & $10.9 \pm 0.01$ & $50 \pm 2.1$ & $146 \pm 20.1$ & $23.0 \pm 0$ & $133.5 \pm 0.7$ & $2395 \pm 27.6$ \\
\hline & 3 & $(\mathrm{CV}=0.1 \%)$ & $(\mathrm{CV}=4.3 \%)$ & $(\mathrm{CV}=13.8 \%)$ & $(\mathrm{CV}=0 \%)$ & $(\mathrm{CV}=0.5 \%)$ & $(\mathrm{CV}=1.1 \%)$ \\
\hline & & $11.2 \pm 0.05$ & $57 \pm 1.4$ & $150 \pm 16.9$ & $28.5 \pm 0.7$ & $94.0 \pm 0$ & $2303 \pm 27.6$ \\
\hline \multirow[t]{2}{*}{287} & 4 & $(\mathrm{CV}=0.4 \%)$ & $(\mathrm{CV}=2.5 \%)$ & $(\mathrm{CV}=11.2 \%)$ & $(\mathrm{CV}=2.5 \%)$ & $(\mathrm{CV}=0 \%)$ & $(\mathrm{CV}=1.1 \%)$ \\
\hline & 5 & $\begin{array}{l}12.2 \pm 0.02 \\
(\mathrm{CV}=0.2 \%)\end{array}$ & $\begin{array}{l}70 \pm 0.71 \\
(C V=1 \%)\end{array}$ & $\begin{array}{c}120 \pm 5.1 \\
(\mathrm{CV}=4.2 \%)\end{array}$ & $\begin{array}{c}26.5 \pm 0.7 \\
(\mathrm{CV}=2.7 \%)\end{array}$ & $\begin{array}{c}95.5 \pm 0.7 \\
(\mathrm{CV}=0.7 \%)\end{array}$ & $\begin{array}{l}2097 \pm 65.6 \\
(\mathrm{CV}=3.1 \%)\end{array}$ \\
\hline \multirow[t]{3}{*}{288} & & $10.8 \pm 0.06$ & $45 \pm 1.4$ & $107 \pm 4.9$ & $25.0 \pm 0$ & $152.5 \pm 2.1$ & $2277 \pm 59.5$ \\
\hline & 6 & $(\mathrm{CV}=0.6 \%)$ & $(\mathrm{CV}=3.1 \%)$ & $(\mathrm{CV}=4.6 \%)$ & $(\mathrm{CV}=0 \%)$ & $(\mathrm{CV}=1.4 \%)$ & $(\mathrm{CV}=2.6 \%)$ \\
\hline & & $12.7 \pm 0.03$ & $48 \pm 0.71$ & $126 \pm 6.6$ & $34.0 \pm 0$ & $79.0 \pm 1.4$ & $1899 \pm 11.6$ \\
\hline \multirow[t]{3}{*}{289} & 7 & $(\mathrm{CV}=0.2 \%)$ & $(\mathrm{CV}=1.5 \%)$ & $(\mathrm{CV}=5.3 \%)$ & $(\mathrm{CV}=0 \%)$ & $(\mathrm{CV}=1.8 \%)$ & $(\mathrm{CV}=0.6 \%)$ \\
\hline & 8 & $10.9 \pm 0.05$ & $68 \pm 2.8$ & $146 \pm 17.7$ & $27.0 \pm 0$ & $129.0 \pm 1.4$ & $2729 \pm 8.9$ \\
\hline & 8 & $(\mathrm{CV}=0.5 \%)$ & $(\mathrm{CV}=4.2 \%)$ & $(\mathrm{CV}=11.8 \%)$ & $(\mathrm{CV}=0 \%)$ & $(\mathrm{CV}=1.1 \%)$ & $(\mathrm{CV}=0.33 \%)$ \\
\hline 290 & 9 & $\begin{array}{l}12.3 \pm 0.11 \\
(\mathrm{CV}=0.9 \%)\end{array}$ & $\begin{array}{c}67 \pm 0.71 \\
(\mathrm{CV}=1.1 \%)\end{array}$ & $\begin{array}{c}92 \pm 4.4 \\
(\mathrm{CV}=4.8 \%)\end{array}$ & (c) & ( & (1) \\
\hline \multirow[t]{3}{*}{291} & 10 & $\begin{array}{l}10.8 \pm 0.11 \\
(\mathrm{CV}=1 \%)\end{array}$ & $\begin{array}{c}70 \pm 1.4 \\
(\mathrm{CV}=2 \%)\end{array}$ & $\begin{array}{c}126 \pm 3.2 \\
(\mathrm{CV}=2.5 \%)\end{array}$ & - & - & - \\
\hline & 11 & $12.8 \pm 0.03$ & $72 \pm 2.1$ & $211 \pm 7.2$ & $29.0 \pm 0$ & $99.5 \pm 0.7$ & $2170 \pm 0.1$ \\
\hline & 11 & $(\mathrm{CV}=0.2 \%)$ & $(\mathrm{CV}=3 \%)$ & $(\mathrm{CV}=3.4 \%)$ & $(\mathrm{CV}=0 \%)$ & $(\mathrm{CV}=0.7 \%)$ & $(\mathrm{CV}=0 \%)$ \\
\hline \multirow[t]{3}{*}{292} & & $13.0 \pm 0.06$ & $78 \pm 2.1$ & $223 \pm 12.1$ & $27.5 \pm 0.7$ & $117.0 \pm 1.4$ & $2646 \pm 26.5$ \\
\hline & 12 & $(\mathrm{CV}=0.4 \%)$ & $(\mathrm{CV}=2.7 \%)$ & $(\mathrm{CV}=5.4 \%)$ & $(\mathrm{CV}=0.6 \%)$ & $(\mathrm{CV}=1.2 \%)$ & $(\mathrm{CV}=1 \%)$ \\
\hline & 13 & $13.8 \pm 0.06$ & $70 \pm 0.71$ & $242 \pm 12.3$ & $32.5 \pm 0.7$ & $105.5 \pm 0.7$ & $2679 \pm 96.7$ \\
\hline \multirow[t]{3}{*}{293} & 13 & $(\mathrm{CV}=0.5 \%)$ & $(\mathrm{CV}=0.5 \%)$ & $(\mathrm{CV}=5.1 \%)$ & $(\mathrm{CV}=2.2 \%)$ & $(\mathrm{CV}=0.7 \%)$ & $(\mathrm{CV}=3.6 \%)$ \\
\hline & 14 & $13.3 \pm 0.01$ & $87 \pm 1.4$ & $182 \pm 11.8$ & $24.5 \pm 0.7$ & $133.0 \pm 1.4$ & $2836 \pm 118.9$ \\
\hline & 14 & $(\mathrm{CV}=0.1 \%)$ & $(\mathrm{CV}=1.6 \%)$ & $(\mathrm{CV}=6.5 \%)$ & $(\mathrm{CV}=2.9 \%)$ & $(\mathrm{CV}=1.1 \%)$ & $(\mathrm{CV}=4.2 \%)$ \\
\hline \multirow[t]{3}{*}{294} & & $12.0 \pm 0.02$ & $72 \pm 1.4$ & $221 \pm 10.4$ & $25.5 \pm 0.7$ & $141.5 \pm 0.7$ & $2495 \pm 15.9$ \\
\hline & 15 & $(\mathrm{CV}=0.2 \%)$ & $(\mathrm{CV}=2 \%)$ & $(\mathrm{CV}=4.7 \%)$ & $(\mathrm{CV}=2.8 \%)$ & $(\mathrm{CV}=0.5 \%)$ & $(\mathrm{CV}=0.64 \%)$ \\
\hline & & $13.2 \pm 0.06$ & $61 \pm 3.5$ & $219 \pm 9.3$ & $32.0 \pm 0$ & $91.5 \pm 0.7$ & $1918 \pm 6.2$ \\
\hline 295 & 16 & $(\mathrm{CV}=0.4 \%)$ & $(\mathrm{CV}=5.8 \%)$ & $(\mathrm{CV}=4.3 \%)$ & $(\mathrm{CV}=0 \%)$ & $(\mathrm{CV}=0.8 \%)$ & $(\mathrm{CV}=0.32 \%)$ \\
\hline & 17 & $12.4 \pm 0.04$ & $80 \pm 3.5$ & $215 \pm 21.6$ & $24.0 \pm 0$ & $156.0 \pm 1.4$ & $2909 \pm 32.7$ \\
\hline & 17 & $(\mathrm{CV}=0.3 \%)$ & $(\mathrm{CV}=4.4 \%)$ & $(\mathrm{CV}=10 \%)$ & $(\mathrm{CV}=0 \%)$ & $(0.9 \%)$ & $(\mathrm{CV}=1.1 \%)$ \\
\hline 296 & & $12.6 \pm 0.01$ & $54 \pm 3.5$ & $220 \pm 12.2$ & $29.5 \pm 0.7$ & $90.0 \pm 0$ & $2212 \pm 23.9$ \\
\hline & 18 & $(\mathrm{CV}=0.1 \%)$ & $(\mathrm{CV}=6.6 \%)$ & $(\mathrm{CV}=5.5 \%)$ & $(\mathrm{CV}=2.4 \%)$ & $(\mathrm{CV}=0 \%)$ & $(\mathrm{CV}=1.08 \%)$ \\
\hline & 19 & $13.9 \pm 0.03$ & $74 \pm 1.4$ & $191 \pm 15.1$ & $33.0 \pm 0$ & $100.0 \pm 0$ & $2274 \pm 22.6$ \\
\hline 297 & 19 & $(\mathrm{CV}=0.2 \%)$ & $(\mathrm{CV}=1.9 \%)$ & $(\mathrm{CV}=7.9 \%)$ & $(\mathrm{CV}=0 \%)$ & $(\mathrm{CV}=0 \%)$ & $(\mathrm{CV}=1 \%)$ \\
\hline & 20 & $13.8 \pm 0.06$ & $62 \pm 2.8$ & $206 \pm 10.6$ & $35.0 \pm 0$ & $95.5 \pm 0.7$ & $2396 \pm 12.4$ \\
\hline & 20 & $(\mathrm{CV}=0.5 \%)$ & $(\mathrm{CV}=4.6 \%)$ & $(\mathrm{CV}=5.1 \%)$ & $(\mathrm{CV}=0 \%)$ & $(\mathrm{CV}=0.7 \%)$ & $(\mathrm{CV}=0.5 \%)$ \\
\hline 298 & 21 & $14.1 \pm 0.05$ & $95 \pm 0.71$ & $369 \pm 46.5$ & $28.5 \pm 0.7$ & $158.5 \pm 3.5$ & $3641 \pm 2.7$ \\
\hline & 21 & $(\mathrm{CV}=0.4 \%)$ & $(\mathrm{CV}=0.7 \%)$ & $(\mathrm{CV}=12.6 \%)$ & $(\mathrm{CV}=2.5 \%)$ & $(\mathrm{CV}=2.2 \%)$ & $(\mathrm{CV}=0.07 \%)$ \\
\hline & 22 & $15.0 \pm 0.1$ & $91 \pm 2.1$ & $411 \pm 20.3$ & $36.5 \pm 0.7$ & $111.5 \pm 2.1$ & $3052 \pm 29.7$ \\
\hline 299 & 22 & $(\mathrm{CV}=0.7 \%)$ & $(\mathrm{CV}=2.3 \%)$ & $(\mathrm{CV}=4.95)$ & $(\mathrm{CV}=1.9 \%)$ & $(\mathrm{CV}=1.9 \%)$ & $(\mathrm{CV}=0.97 \%)$ \\
\hline & & $13.0 \pm 0.11$ & $84 \pm 1.4$ & $303 \pm 8.8$ & $29.0 \pm 0$ & $121.5 \pm 2.1$ & $2759 \pm 70.1$ \\
\hline & 23 & $(\mathrm{CV}=0.9 \%)$ & $(\mathrm{CV}=1.7 \%)$ & $(\mathrm{CV}=2.9 \%)$ & $(\mathrm{CV}=0 \%)$ & $(\mathrm{CV}=1.7 \%)$ & $(\mathrm{CV}=2.5 \%)$ \\
\hline 300 & & $13.4 \pm 0.07$ & $93 \pm 1.41$ & $346 \pm 57.9$ & $34.5 \pm 0.7$ & $103.5 \pm 0.7$ & $3076 \pm 3.8$ \\
\hline & 24 & $(C V=0.5 \%)$ & $(\mathrm{CV}=1.5 \%)$ & $(\mathrm{CV}=16.7 \%)$ & $(\mathrm{CV}=2.0 \%)$ & $(\mathrm{CV}=0.7 \%)$ & $(\mathrm{CV}=0.12 \%)$ \\
\hline & 25 & $13.8 \pm 0.06$ & $90 \pm 1.4$ & $279 \pm 16.4$ & $34.0 \pm 0$ & $104.5 \pm 0.7$ & $2552 \pm 7.4$ \\
\hline 301 & 25 & $(\mathrm{CV}=0.4 \%)$ & $(\mathrm{CV}=1.6 \%)$ & $(\mathrm{CV}=5.9 \%)$ & $(\mathrm{CV}=0 \%)$ & $(\mathrm{CV}=0.7 \%)$ & $(\mathrm{CV}=0.29 \%)$ \\
\hline & 26 & $13.1 \pm 0.12$ & $97 \pm 0.71$ & $363 \pm 19.3$ & $35.0 \pm 0$ & $101.0 \pm 1.4$ & $2603 \pm 6.9$ \\
\hline & 26 & $(\mathrm{CV}=0.9 \%)$ & $(\mathrm{CV}=0.7 \%)$ & $(\mathrm{CV}=5.3 \%)$ & $(0 \%)$ & $(\mathrm{CV}=1.4 \%)$ & $(\mathrm{CV}=0.27 \%)$ \\
\hline 302 & & $13.6 \pm 0.12$ & $86 \pm 2.83$ & $333 \pm 23.86$ & $34.0 \pm 0$ & $95.5 \pm 0.7$ & $2472 \pm 91.9$ \\
\hline & 21 & $(\mathrm{CV}=0.9 \%)$ & $(\mathrm{CV}=3.3 \%)$ & $(\mathrm{CV}=7.2 \%)$ & $(\mathrm{CV}=0 \%)$ & $(\mathrm{CV}=0.7 \%)$ & $(\mathrm{CV}=3.7 \%)$ \\
\hline & 28 & $13.5 \pm 0.08$ & $89 \pm 0.71$ & $313 \pm 29.56$ & $37.5 \pm 2.1$ & $124.0 \pm 0$ & $2562 \pm 88.9$ \\
\hline & 28 & $(\mathrm{CV}=0.6 \%)$ & $(\mathrm{CV}=0.8 \%)$ & $(\mathrm{CV}=9.4 \%)$ & $(\mathrm{CV}=5.7 \%)$ & $(\mathrm{CV}=0 \%)$ & $(\mathrm{CV}=3.5 \%)$ \\
\hline & 29 & $13.7 \pm 0.07$ & $80 \pm 1.4$ & $290 \pm 14.8$ & $31.5 \pm 0.7$ & $109.0 \pm 2.8$ & $2556 \pm 99.6$ \\
\hline & 29 & $(\mathrm{CV}=0.5 \%)$ & $(\mathrm{CV}=1.8 \%)$ & $(\mathrm{CV}=5.1 \%)$ & $(\mathrm{CV}=0.2 \%)$ & $(\mathrm{CV}=2.2 \%)$ & $(\mathrm{CV}=3.9 \%)$ \\
\hline 304 & 30 & $13.5 \pm 0.11$ & $90 \pm 0.71$ & $296 \pm 14.1$ & $28.0 \pm 0$ & $151.0 \pm 0$ & $3217 \pm 50.11$ \\
\hline & 30 & $(\mathrm{CV}=0.8 \%)$ & $(\mathrm{CV}=0.8 \%)$ & $(\mathrm{CV}=4.8 \%)$ & $(\mathrm{CV}=0 \%)$ & $(\mathrm{CV}=0 \%)$ & $(\mathrm{CV}=1.56 \%)$ \\
\hline
\end{tabular}


306

Table III

307

308

309

310

311

312

313

314

315

316

317

318

319

320

321

322

323

324

325

326

327

328

$329 *$ The overall score is the average of the means for stickiness, bulkiness, and firmness.

Sensory quality of pasta samples

\begin{tabular}{|c|c|c|c|c|}
\hline \multirow{2}{*}{$\begin{array}{l}\text { Semolina } \\
\text { samples }\end{array}$} & \multicolumn{4}{|c|}{ Pasta sensory quality } \\
\hline & Stickiness & Firmness & Bulkiness & Overall score \\
\hline 1 & $60.0 \pm 2.5$ & $60.0 \pm 2.5$ & $60.0 \pm 2.5$ & $60.0 \pm 2.5$ \\
\hline 2 & $50.0 \pm 2.5$ & $60.0 \pm 2.5$ & $50.0 \pm 2.5$ & $53.3 \pm 2.5$ \\
\hline 3 & $35.0 \pm 7.5$ & $60.0 \pm 4.2$ & $40.0 \pm 2.5$ & $45.0 \pm 4.2$ \\
\hline 4 & $40.0 \pm 2.5$ & $60.0 \pm 2.5$ & $43.0 \pm 7.5$ & $47.8 \pm 7.5$ \\
\hline 5 & $50.0 \pm 2.5$ & $60.0 \pm 2.5$ & $50.0 \pm 2.5$ & $53.3 \pm 2.5$ \\
\hline 6 & $40 \pm 2.5$ & $60.0 \pm 2.55$ & $43.3 \pm 7.5$ & $47.8 \pm 4.2$ \\
\hline 7 & $50.0 \pm 2.5$ & $50.0 \pm 2.5$ & $50.0 \pm 2.5$ & $50.0 \pm 2.5$ \\
\hline 8 & $43.3 \pm 7.5$ & $65.0 \pm 7.5$ & $43.3 \pm 7.5$ & $50.5 \pm 5.0$ \\
\hline 9 & $40.0 \pm 2.5$ & $70.0 \pm 4.5$ & $45.0 \pm 7.5$ & $51.7 \pm 4.2$ \\
\hline 10 & $40.0 \pm 2.5$ & $71.7 \pm 5.0$ & $45.0 \pm 7.5$ & $52.2 \pm 5.0$ \\
\hline 11 & $50.0 \pm 2.5$ & $60.0 \pm 2.5$ & $50.0 \pm 2.5$ & $53.3 \pm 2.5$ \\
\hline 12 & $55.0 \pm 7.5$ & $63.3 \pm 7.5$ & $55.0 \pm 7.5$ & $57.8 \pm 7.5$ \\
\hline 13 & $50.0 \pm 2.5$ & $60.0 \pm 2.5$ & $50.0 \pm 2.5$ & $53.3 \pm 2.5$ \\
\hline 14 & $60.0 \pm 2.5$ & $70.0 \pm 2.5$ & $60.0 \pm 2.5$ & $63.3 \pm 2.5$ \\
\hline 15 & $40.0 \pm 2.5$ & $70.0 \pm 2.5$ & $40.0 \pm 2.5$ & $50.0 \pm 2.5$ \\
\hline 16 & $50.0 \pm 2.5$ & $70.0 \pm 2.5$ & $50.0 \pm 2.5$ & $56.7 \pm 2.5$ \\
\hline 17 & $50.0 \pm 2.5$ & $60.0 \pm 2.5$ & $53.3 \pm 5.0$ & $54.4 \pm 3.3$ \\
\hline 18 & $50.0 \pm 2.5$ & $60.0 \pm 2.5$ & $55.0 \pm 7.5$ & $55.0 \pm 4.2$ \\
\hline 19 & $53.3 \pm 7.5$ & $70.0 \pm 2.5$ & $50.0 \pm 2.5$ & $57.8 \pm 4.2$ \\
\hline 20 & $60.0 \pm 2.5$ & $63.3 \pm 7.5$ & $56.7 \pm 7.5$ & $60.0 \pm 5.8$ \\
\hline 21 & $70.0 \pm 2.5$ & $70.0 \pm 2.5$ & $70.0 \pm 2.5$ & $70.0 \pm 2.5$ \\
\hline 22 & $65.0 \pm 7.5$ & $73.3 \pm 5.0$ & $63.3 \pm 7.5$ & $67.2 \pm 5.8$ \\
\hline 23 & $60.0 \pm 2.5$ & $75.0 \pm 7.5$ & $60.0 \pm 2.5$ & $65.0 \pm 4.2$ \\
\hline 24 & $60.0 \pm 2.5$ & $70.0 \pm 2.5$ & $60.0 \pm 2.5$ & $63.3 \pm 2.5$ \\
\hline 25 & $60.0 \pm 2.5$ & $66.7 \pm 7.5$ & $56.7 \pm 7.5$ & $61.1 \pm 5.8$ \\
\hline 26 & $53.3 \pm 7.5$ & $63.0 \pm 7.5$ & $55.0 \pm 7.5$ & $57.2 \pm 7.5$ \\
\hline 27 & $60.0 \pm 2.5$ & $70.0 \pm 2.5$ & $60.0 \pm 2.5$ & $63.3 \pm 2.5$ \\
\hline 28 & $56.7 \pm 7.5$ & $73.3 \pm 7.5$ & $55.0 \pm 7.5$ & $61.7 \pm 7.5$ \\
\hline 29 & $55.0 \pm 7.5$ & $70.0 \pm 2.5$ & $50.0 \pm 2.5$ & $58.3 \pm 4.2$ \\
\hline 30 & $55.0 \pm 7.5$ & $80.0 \pm 2.5$ & $55.0 \pm 7.5$ & $63.3 \pm 5.8$ \\
\hline
\end{tabular}

330 
331

332 332
Table IV

Correlation coefficients of Glutopeak and conventional indices

\begin{tabular}{ccccccc}
\hline & $\begin{array}{c}\text { Peak } \\
\text { maximum } \\
\text { time }\end{array}$ & $\begin{array}{c}\text { Maximum } \\
\text { torque }\end{array}$ & Energy & Protein & $\begin{array}{c}\text { Gluten } \\
\text { index }\end{array}$ & $\begin{array}{c}\text { W } \\
\text { Alveographic }\end{array}$ \\
\hline $\begin{array}{c}\text { Peak maximum } \\
\text { time }\end{array}$ & 1 & & & & & \\
Maximum torque & $0.56^{* *}$ & 1 & & & & \\
Energy & $0.88^{* *}$ & $0.75^{* *}$ & 1 & & & \\
Protein & n.s. & $0.54^{* *}$ & $0.47^{* *}$ & 1 & & \\
Gluten index & n.s. & n.s. & $0.47^{* *}$ & $0.69^{* *}$ & 1 & \\
W Alveographic & $0.35^{*}$ & $0.56^{* *}$ & $0.65^{* *}$ & $0.75^{* *}$ & $0.80^{* *}$ & 1 \\
\hline
\end{tabular}

$* \mathrm{p}<0.05$

$335 * * \mathrm{p}<0.01$

336 n.s., not significant 


\section{Table V}

339 Correlation coefficients of pasta quality attributes and rheological indices

340

\begin{tabular}{|c|c|c|c|c|c|c|c|c|}
\hline & \multicolumn{2}{|c|}{ Stickiness } & \multicolumn{2}{|c|}{ Firmness } & \multicolumn{2}{|c|}{ Bulkiness } & \multicolumn{2}{|c|}{ Overall score } \\
\hline & $\begin{array}{l}\text { All samples } \\
\quad(n=30)\end{array}$ & $\begin{array}{c}\text { Samples with } \\
30<\mathrm{GI}<65 \\
(\mathrm{n}=9)\end{array}$ & $\begin{array}{l}\text { All samples } \\
\qquad(\mathrm{n}=30)\end{array}$ & $\begin{array}{c}\text { Samples with } \\
30<\mathrm{GI}<65 \\
(\mathrm{n}=9)\end{array}$ & $\begin{array}{l}\text { All samples } \\
\quad(n=30)\end{array}$ & $\begin{array}{c}\text { Samples with } \\
30<\mathrm{GI}<65 \\
(\mathrm{n}=9)\end{array}$ & $\begin{array}{l}\text { All samples } \\
\quad(n=30)\end{array}$ & $\begin{array}{c}\text { Samples with } \\
30<\mathrm{GI}<65 \\
(\mathrm{n}=9)\end{array}$ \\
\hline Gluten Index & $0.52 * * *$ & n.s. & $0.65 * * *$ & n.s. & $0.50 * * *$ & n.s. & $0.65 * * *$ & n.s. \\
\hline Maximum torque & $0.55 * * *$ & $0.60 * *$ & n.s. & n.s. & $0.42 * * *$ & $0.49 *$ & $0.38 * *$ & $0.51 *$ \\
\hline Peak maximum time & n.s & $-0.66^{* *}$ & n.s. & n.s. & n.s. & $-0.67 * * *$ & n.s. & $-0.59 * *$ \\
\hline Energy & $0.55 * * *$ & n.s. & n.s. & n.s. & $0.50 * * *$ & n.s. & $0.49 * * *$ & n.s. \\
\hline W Alveographic & $0.69 * * *$ & n.s. & $0.54 * * *$ & $0.55 *$ & $0.68 * * *$ & n.s. & $0.76 * * *$ & n.s. \\
\hline
\end{tabular}

341

$342 * \mathrm{p}<0.1$

$343 * * \mathrm{p}<0.05$

$344 * * * \mathrm{p}<0.01$

345 n.s., not significant

346 
347 Fig. 1 Curve of semolina sample produced by GlutoPeak software during a test. The variables of 348 importance are highlighted: maximum torque, peak maximum time, and area under the peak. $\mathrm{t} 1, \mathrm{t} 2$, 349 and $\mathrm{t} 3$ represent the sampling times for microscopic observations.

350 Fig. 2 Semolina classification: ability of Gluten Index (a) and GlutoPeak curve area (b) to

351 discriminate semolina samples according to the current method based on W alveographic index.

352 A.U., Arbitrary Unit

353 Fig. 3 Microscopic images of $\operatorname{good}(A, C, E)$ and poor (B, D, F) quality semolina at first stage of 354 mixing (A, B), after gluten formation (C, D), and after its breakdown (E, F). 


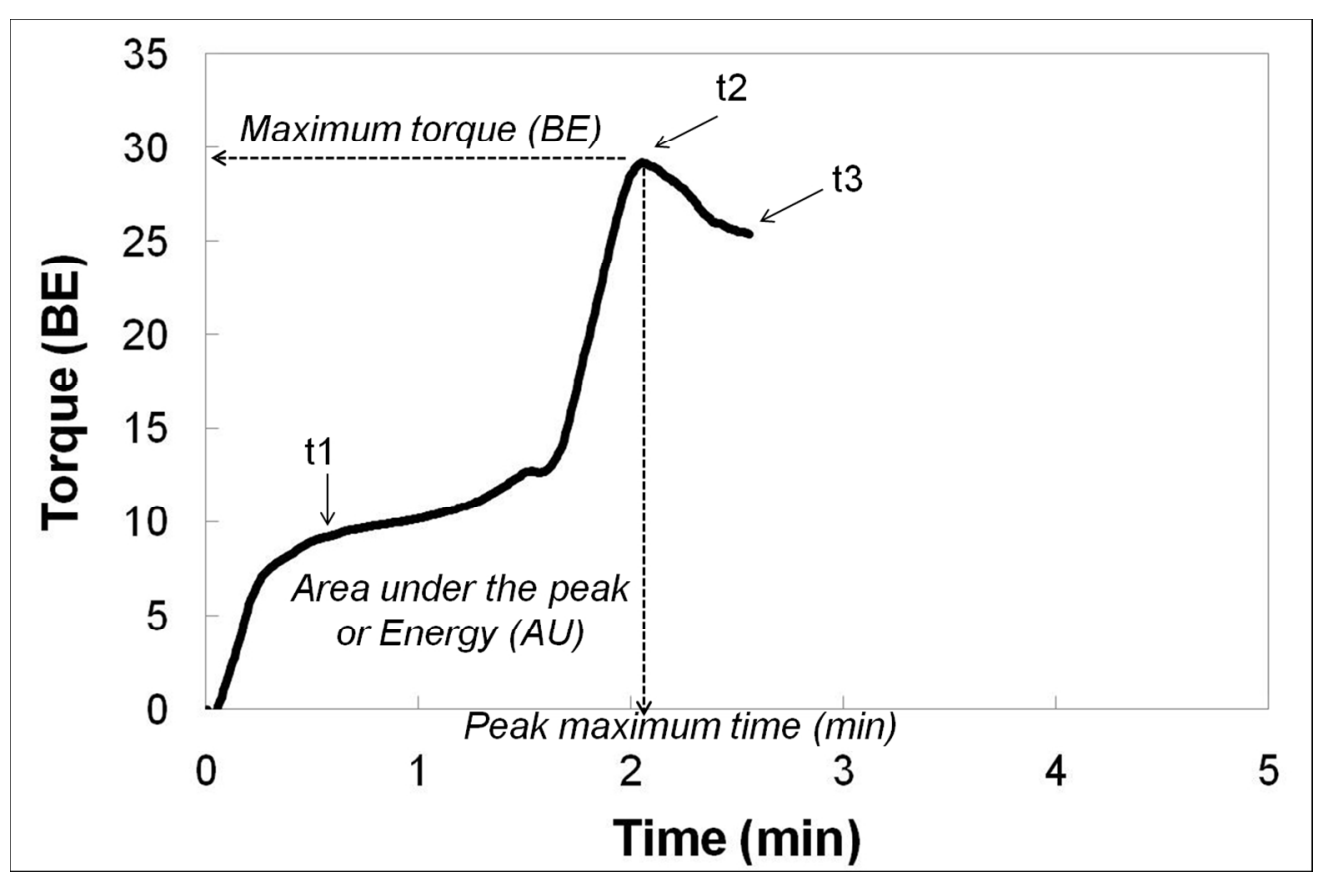

Fig. 1 Curve of semolina sample produced by GlutoPeak software during a test. The variables of importance are highlighted: maximum torque, peak maximum time, and area under the peak. $\mathrm{t} 1, \mathrm{t} 2$, and $\mathrm{t} 3$ represent the sampling times for microscopic observations.

$245 \times 160 \mathrm{~mm}(150 \times 150 \mathrm{DPI})$ 


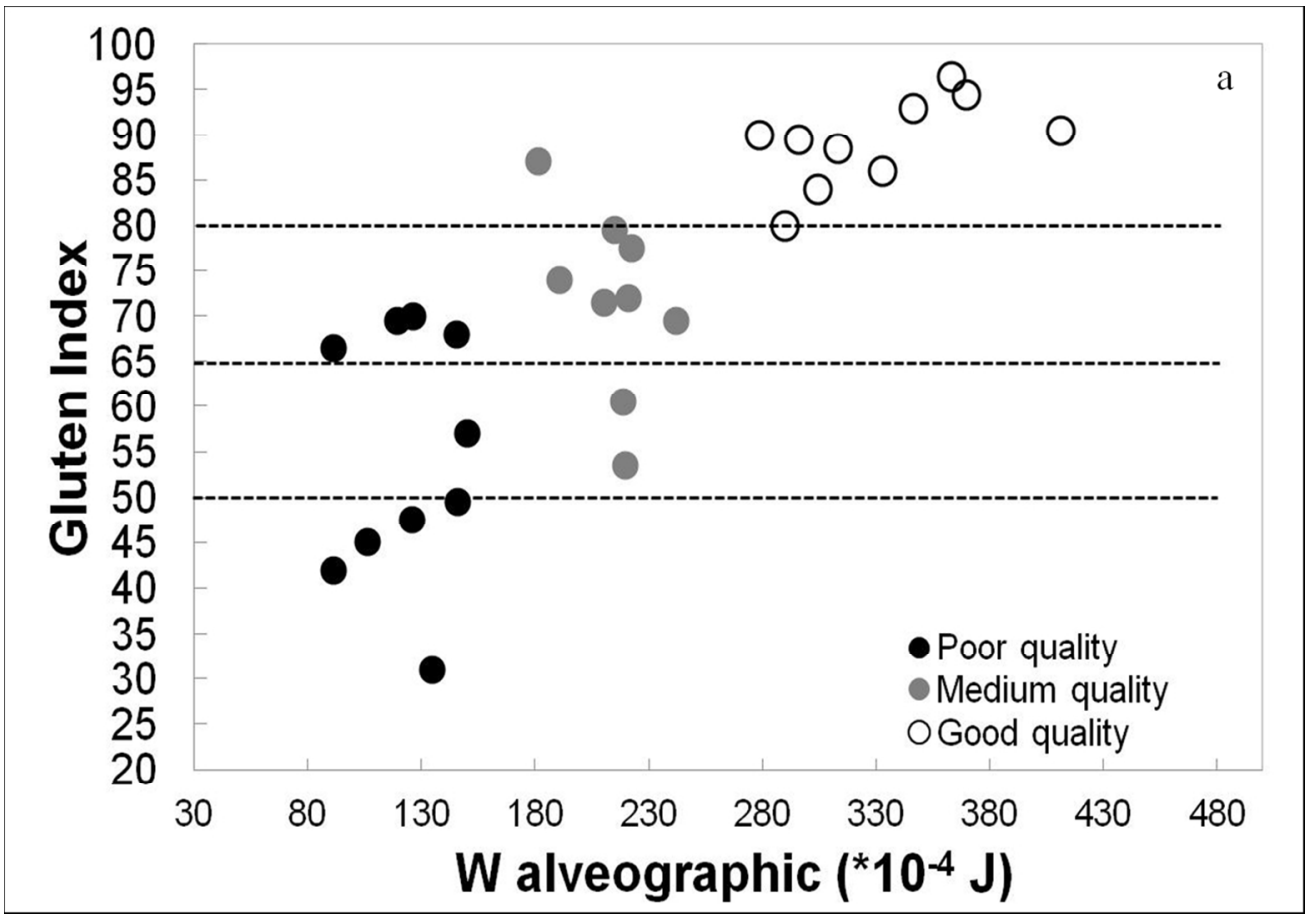

Fig. 2 Semolina classification: ability of Gluten Index (a) and GlutoPeak curve area (b) to discriminate semolina samples according to the current method based on $\mathrm{W}$ alveographic index. A.U., Arbitrary Unit 


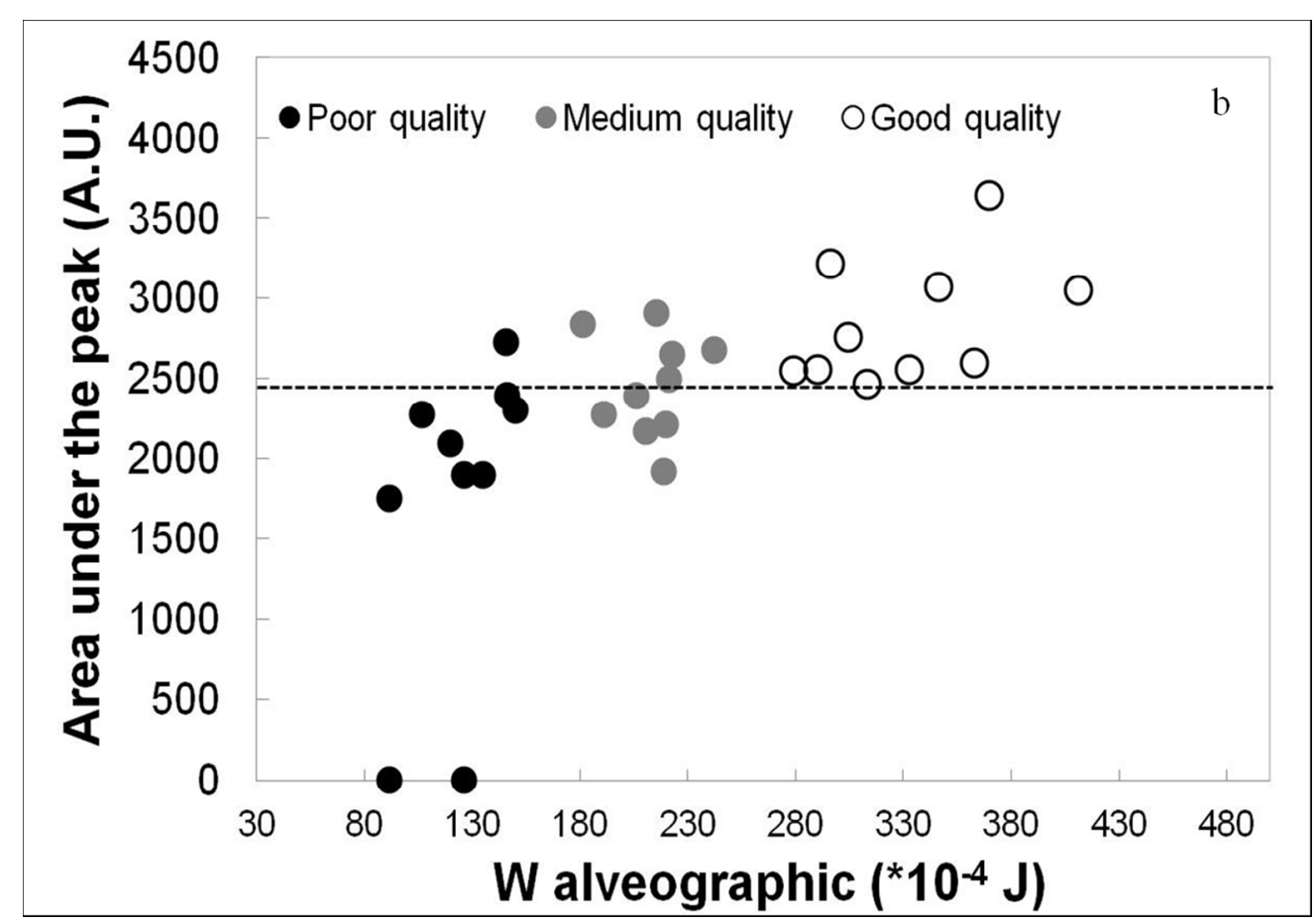

Fig. 2 Semolina classification: ability of Gluten Index (a) and GlutoPeak curve area (b) to discriminate semolina samples according to the current method based on $\mathrm{W}$ alveographic index. A.U., Arbitrary Unit $216 \times 150 \mathrm{~mm}(150 \times 150 \mathrm{DPI})$ 
Fig. 3 Microscopic images of good $(A, C, E)$ and poor $(B, D, F)$ quality semolina at first stage of mixing ( $A$, $B)$, after gluten formation $(C, D)$, and after its breakdown $(E, F)$. $86 \times 65 \mathrm{~mm}(150 \times 150 \mathrm{DPI})$ 


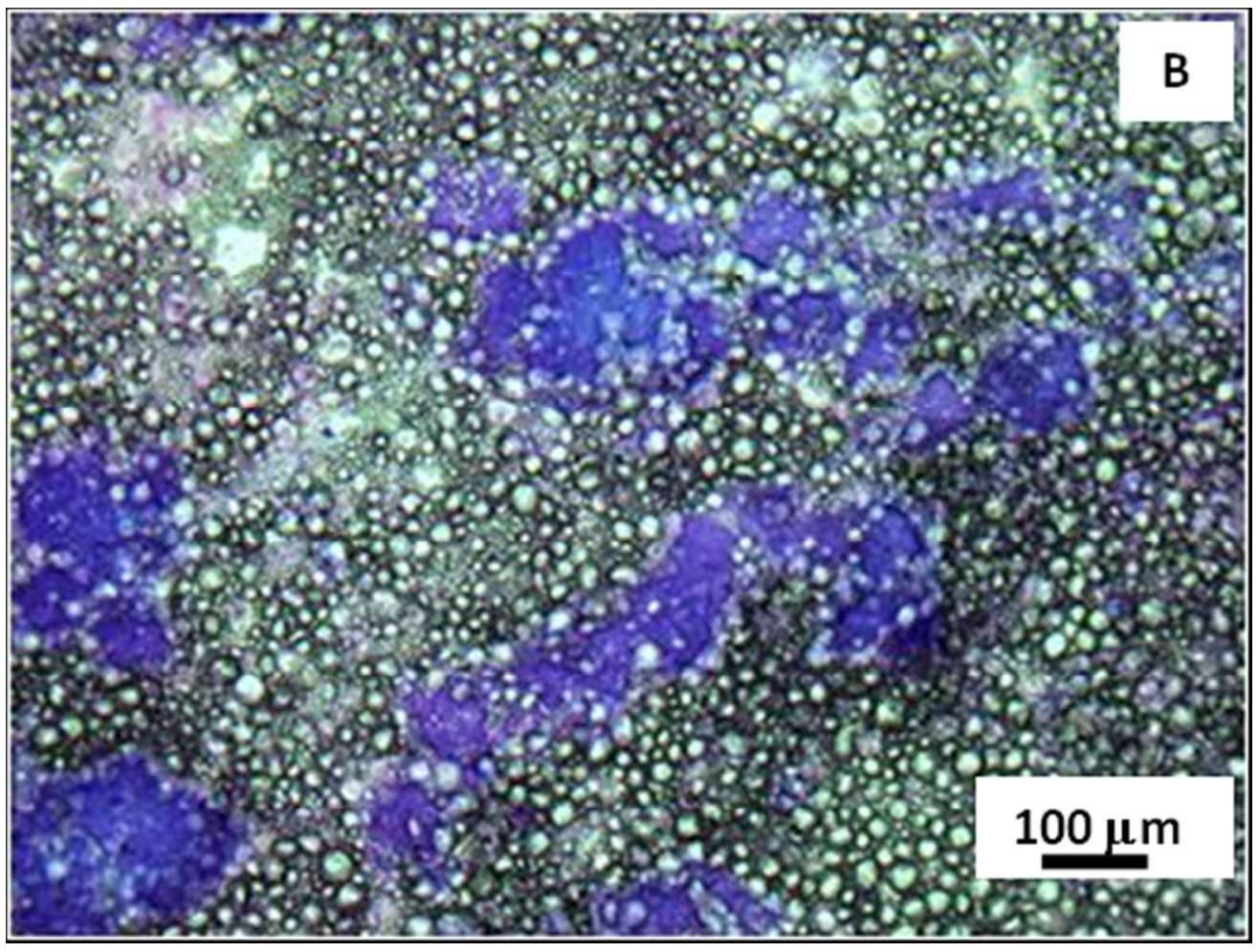

Fig. 3 Microscopic images of good $(A, C, E)$ and poor $(B, D, F)$ quality semolina at first stage of mixing ( $A$, $B)$, after gluten formation $(C, D)$, and after its breakdown $(E, F)$. $86 \times 65 \mathrm{~mm}(150 \times 150 \mathrm{DPI})$ 


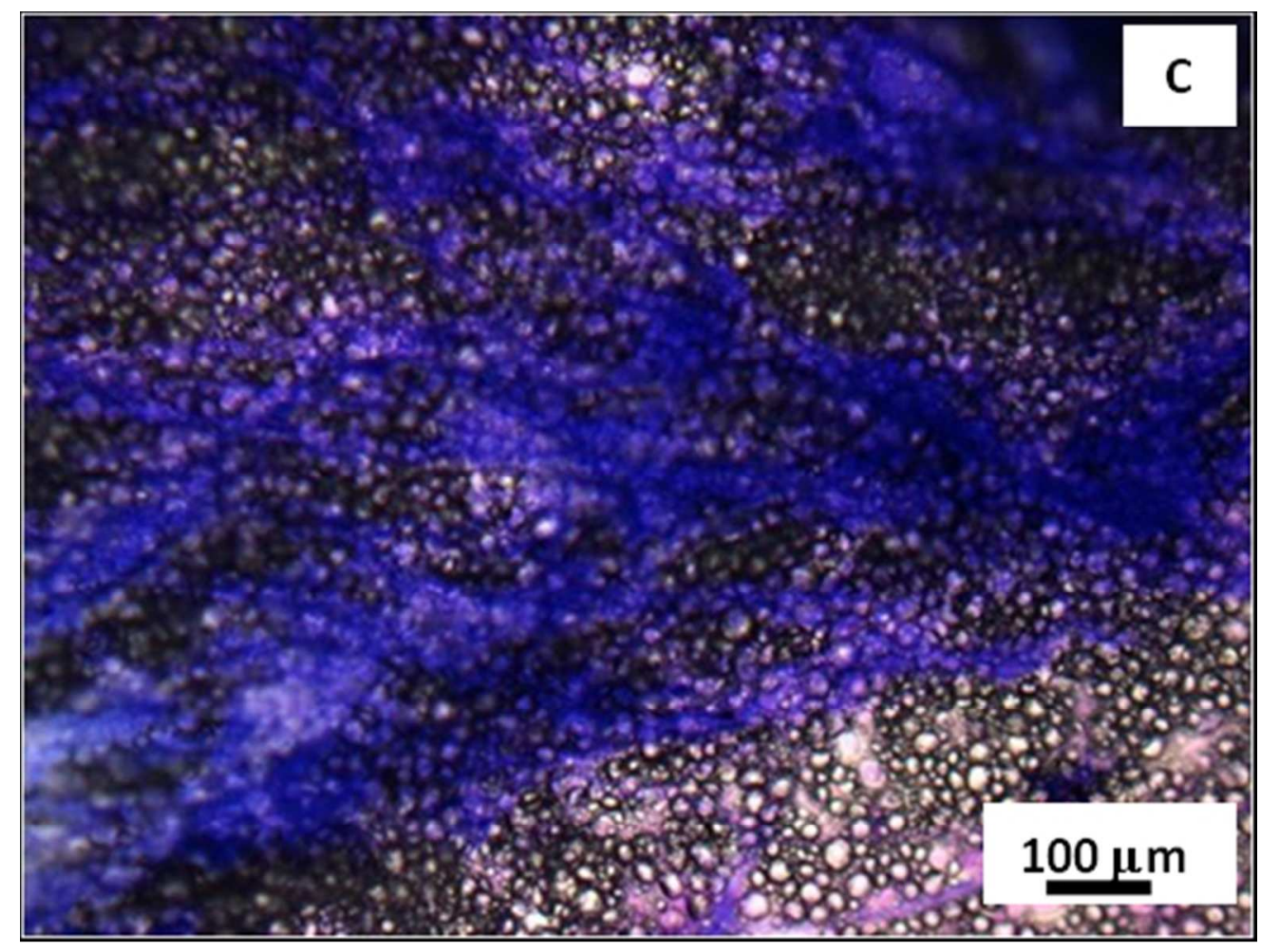

Fig. 3 Microscopic images of good $(A, C, E)$ and poor $(B, D, F)$ quality semolina at first stage of mixing ( $A$, $B)$, after gluten formation $(C, D)$, and after its breakdown $(E, F)$. $86 \times 65 \mathrm{~mm}(150 \times 150 \mathrm{DPI})$ 


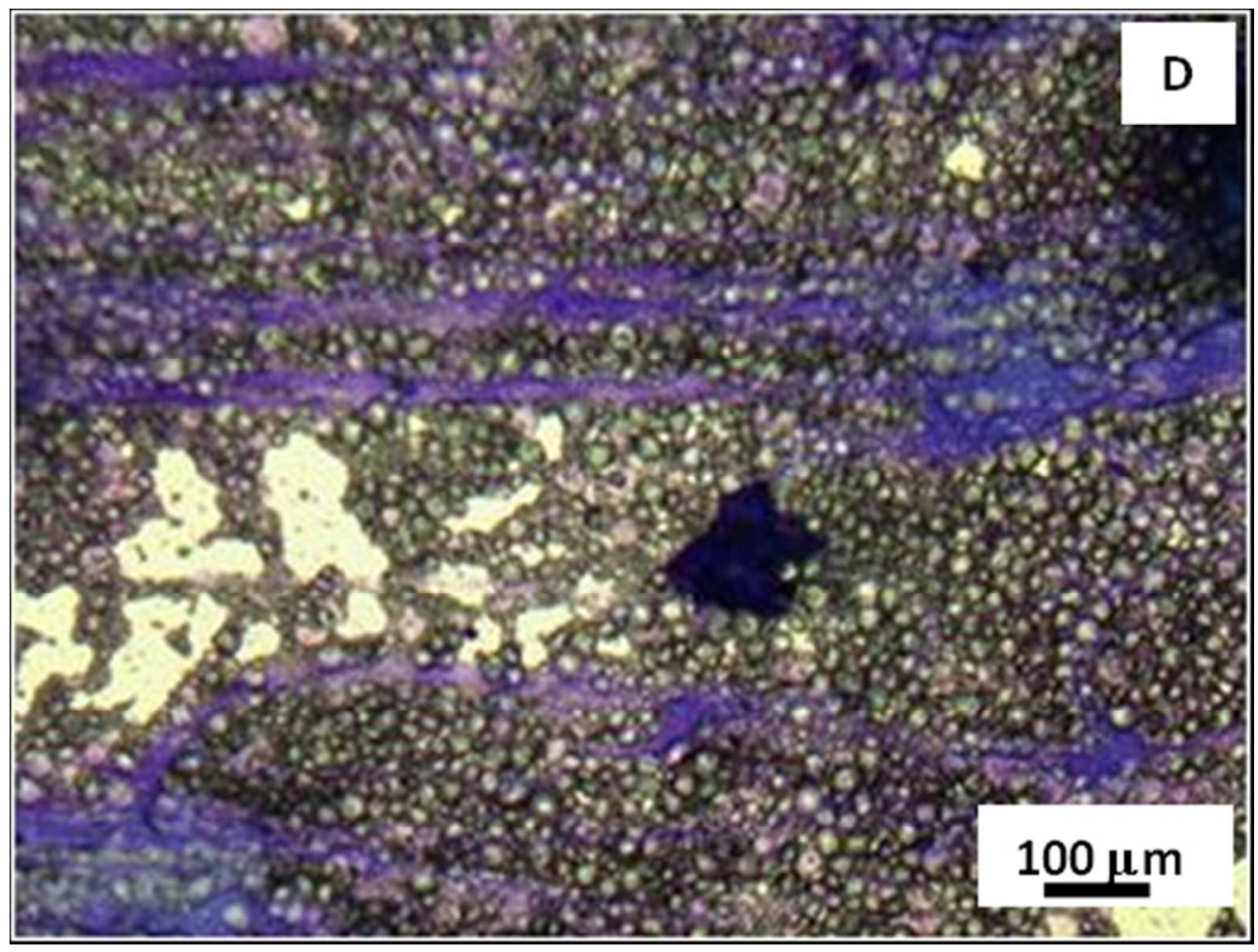

Fig. 3 Microscopic images of good $(A, C, E)$ and poor $(B, D, F)$ quality semolina at first stage of mixing (A, $B)$, after gluten formation $(C, D)$, and after its breakdown $(E, F)$. $86 \times 65 \mathrm{~mm}(150 \times 150 \mathrm{DPI})$ 


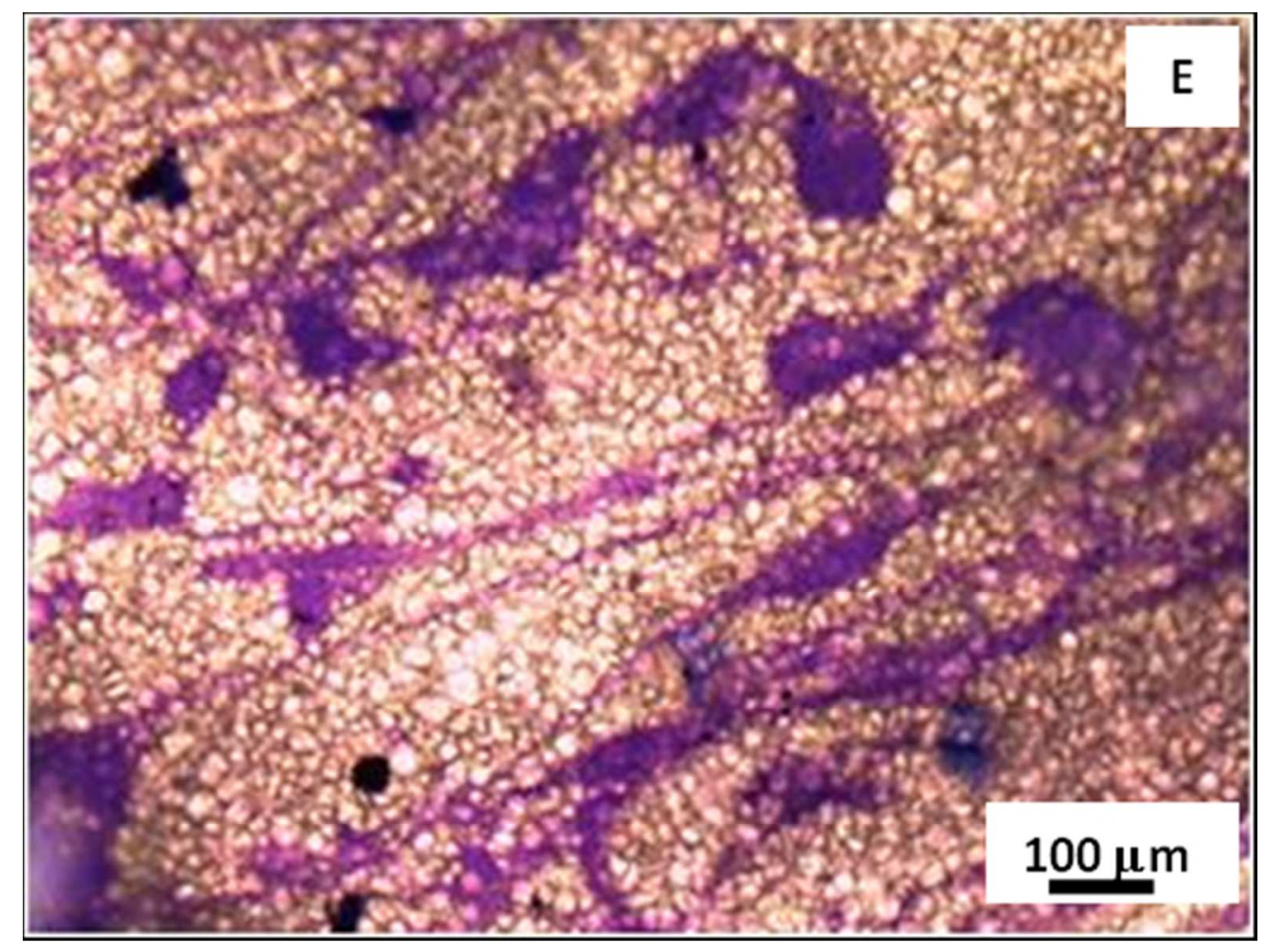

$86 \times 65 \mathrm{~mm}(150 \times 150 \mathrm{DPI})$ 


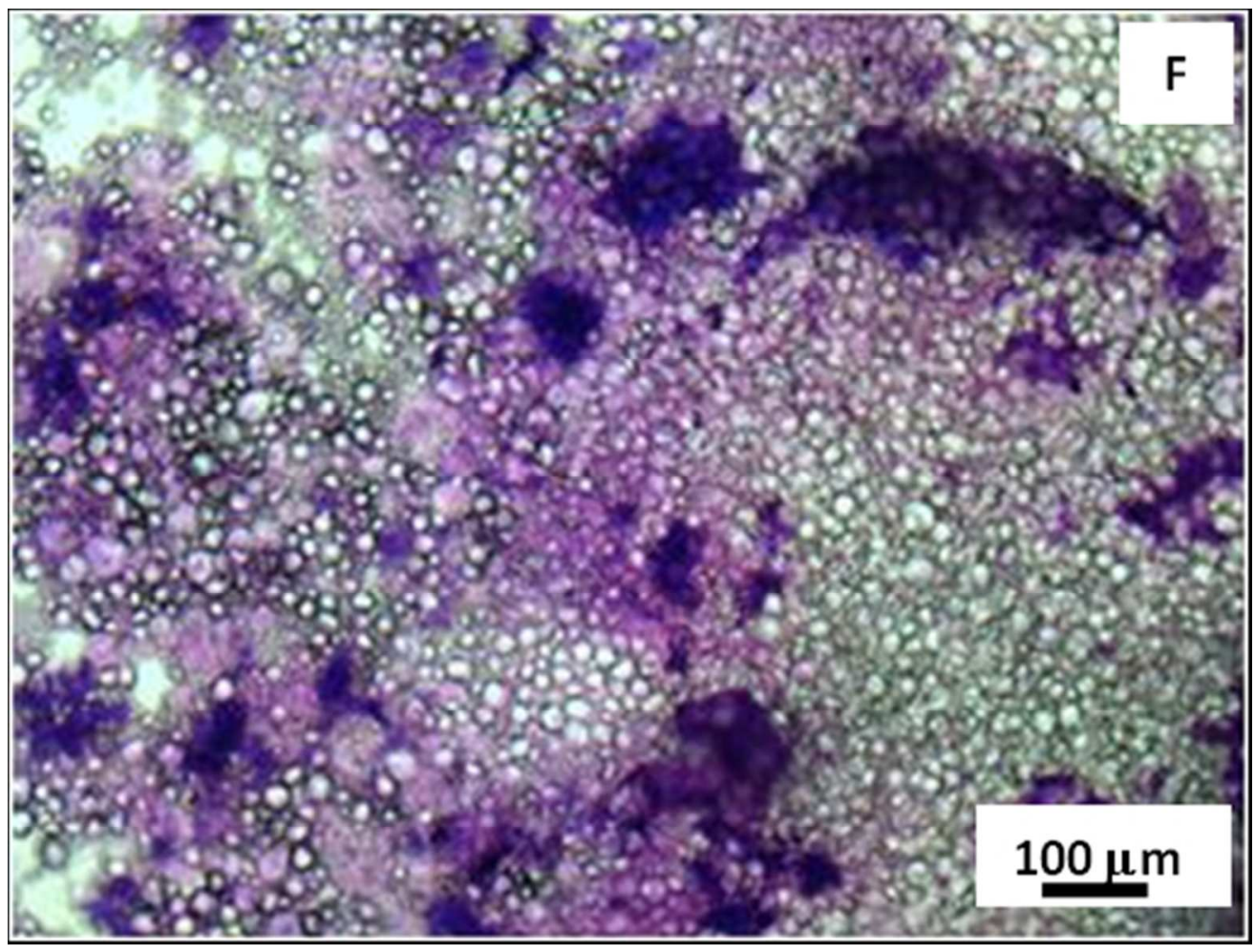

Fig. 3 Microscopic images of good $(A, C, E)$ and poor $(B, D, F)$ quality semolina at first stage of mixing ( $A$, $B)$, after gluten formation $(C, D)$, and after its breakdown $(E, F)$. $86 \times 65 \mathrm{~mm}(150 \times 150 \mathrm{DPI})$ 